\title{
Estrogen action and prostate cancer
}

\author{
Jason L Nelles ${ }^{1}$, Wen-Yang Hu ${ }^{1}$, and Gail S Prins ${ }^{1, \dagger}$ \\ ${ }^{1}$ Department of Urology, University of Illinois at Chicago, 820 South Wood Street, MC 955, \\ Chicago, IL 60612, USA
}

\section{Abstract}

Early work on the hormonal basis of prostate cancer focused on the role of androgens, but more recently estrogens have been implicated as potential agents in the development and progression of prostate cancer. In this article, we review the epidemiological, laboratory and clinical evidence that estrogen may play a causative role in human prostate cancer, as well as rodent and grafted in vivo models. We then review recent literature highlighting potential mechanisms by which estrogen may contribute to prostate cancer, including estrogenic imprinting and epigenetic modifications, direct genotoxicity, hyperprolactinemia, inflammation and immunologic changes, and receptor-mediated actions. We discuss the work performed so far separating the actions of the different known estrogen receptors (ERs), ER $\alpha$ and ER $\beta$, as well as G-protein-coupled receptor 30 and their specific roles in prostate disease. Finally, we predict that future work in this field will involve more investigations into epigenetic changes, experiments using new models of hormonal dysregulation in developing human prostate tissue, and continued delineation of the roles of the different ER subtypes, as well as their downstream signaling pathways that may serve as therapeutic targets.

\section{Keywords}

estradiol; estrogen; prostate cancer; prostate gland

As the most common noncutaneous form of cancer in men, prostate cancer is the subject of over US\$300 million in research funding annually from both the NIH and the National Cancer Institute in the USA, with comparable funding levels in other nations worldwide [201,202]. Despite these significant efforts, the exact mechanism of carcinogenesis is unknown, although it is believed to involve a combination of dietary, environmental, genetic, lifestyle and hormonal causes. While the hormonal regulation of prostate cancer has been studied for over 75 years, the focus has largely been on androgen action. More recent research increasingly suggests a role of estrogen in the etiology and progression of prostate cancer and this article will highlight the evidence on this topic.

Huggins first demonstrated the androgenic dependence of prostate cancer as a potential cause, as well as a point of intervention and therapy, ultimately leading to a Nobel prize in 1966 [1,2]. The finding that castration caused regression of metastatic prostate cancer has

\footnotetext{
(C) 2011 Expert Reviews Ltd

${ }^{\dagger}$ Author for correspondence: Tel.: +1 312413 5253, Fax: +1 312996 9649, gprins@ uic.edu.

Financial \& competing interests disclosure

This work was supported by NIH grants RC2 ES018758, R01 ES015584 and R01 DK40890 to Gail S Prins. The authors have no other relevant affiliations or financial involvement with any organization or entity with a financial interest in or financial conflict with the subject matter or materials discussed in the manuscript apart from those disclosed.

No writing assistance was utilized in the production of this manuscript.
} 
led to decades of research on the role of androgens in prostate cancer, as well as antiandrogen therapy being a mainstay treatment for meta-static disease $[3,4]$ and neoadjuvant therapy prior to treatment in locally advanced disease [5]. In the early era of prostate cancer research, the role of estrogen was primarily seen as an indirect anti-androgen action mediated through feedback inhibition of hypothalamic luteinizing hormone (LHRH) and pituitary luteinizing hormone $(\mathrm{LH})$ release, resulting in decreased testicular androgen synthesis and release. Consequently, administration of exogenous estrogens such as the nonmetabolized diethylstilbestrol (DES) was used to reduce circulating androgens to castrate levels in patients with advanced prostate cancer [4]. Moreover, this method of effective 'chemical castration' was noted to lower the incidence of bone mineral density loss, a known complication of other forms of androgen deprivation therapy that also reduce the level of circulating endogenous estrogen [6,3]. This highlights the fact that estrogens and estrogen analogs play important physiologic roles in normal, healthy adult males [3]. The ability of estrogens to treat or prevent prostate cancer is under continued investigation. It was recently demonstrated that DES may be able to directly affect prostate cancer cell division by inhibiting telemorase [7]. In a xenograft model with human prostate cancer cells injected into castrated severe combined immune-deficient mice, estrogen appears to suppress tissue androgen levels as well as tumor growth, independent of estrogen receptor (ER) blockade [8]. As discussed later, the effects of phytoestrogens have also been investigated for several years as potential agents to prevent prostate cancer.

\section{Estrogens \& prostate disease}

In contrast to the early work on estrogen as a treatment for castration-resistant cancer or as a cancer preventive in the case of phytoestrogens, an ample body of evidence suggests that estrogens may play a critical role in predisposing, or even causing, prostate cancer. In this aspect, it is noteworthy that estradiol- $17 \beta$ has been classified as a carcinogen by the International Agency for Research on Cancer [9-11], primarily based on its association with endometrial and breast carcinoma in women [12-15].

There is correlative evidence in humans that indicates an effect of estrogen on the prostate gland that is conducive to cancer onset. Although circulating estrogen levels may not correlate well with intraprostatic levels, particularly in light of recent evidence of intraprostatic estrogen production, serum values offer an easily accessible surrogate marker to investigate associations between estrogen and prostate cancer risk. Epidemiological data from adult men have shown mixed results, with one prospective study finding an association of elevated plasma estrogens with an increased risk of prostate cancer [16], and another correlating risk with chronically elevated estrogens [17]. However, the Physician's Health Study suggested the opposite finding, with an increasing prostate cancer risk associated with decreasing estradiol levels after adjusting for sex hormone-binding globulin [18]. Additional studies and meta-analyses have failed to show any association between circulating estrogen levels and risk of prostate cancer [19-21]. This divergence in outcomes related to serum steroid levels and prostate cancer risk may, in part, be understood by recent revelations that prostatic tissue has the capacity to produce its own steroids, including androgens and estrogens. While initially discussed in the 1970s and 1980s, technical advances have revived research on intracrine steroid synthesis and metabolism with new findings revealing that local steroid production by prostate tumors, rather than circulating steroids, may be a major player in driving prostate cancer growth in men following androgen ablative therapy [22]. While the current focus of research on the role of intracrine steroids has been on tumoral androgens, it is important to note that aromatase (CYP19), the enzyme that catalyzes estradiol production from testosterone, is altered in prostate cancer tissues [23] and CYP19A1 expression is elevated 30-fold in prostate cancer metastatic tissue, as compared with primary tumors [24]. Elegant studies performed in aromatase-knockout mice 
demonstrated that these animals have a reduced incidence of prostate cancer following exposure to testosterone plus estrogen when compared with wild-type mice. This suggests that in situ production of estrogen, either locally or systemically, remains a factor in this rodent model, even in the presence of exogenously administered estrogen [25]. In this context, it is possible that intraprostatic estradiol synthesis may contribute to prostate cancer onset in addition to playing a role in tumor progression. Finally, there is evidence that local metabolism of estrogen may also play a role. As discussed later, some metabolites of estrogens have been linked to free radical generation and direct genomic damage. A recent analysis of 1983 French men identified an association between polymorphisms in genes related to estrogen metabolism (CYP1B1 and CYP19) and prostate cancer risk [26]. Realtime PCR and histopathological studies have demonstrated that CYP1B1 is more highly expressed in the peripheral zone of the prostate than the transitional or central zones [27,28]. This mirrors the predilection of prostate cancer for the peripheral zone, raising the possibility that local estrogen metabolites produced by the CYP1B1 pathway (e.g., 4-OHestradiol) play an important role in prostate carcinogenesis.

In a recent cross-sectional analysis, serum steroid levels were assayed in 1413 matched men of various races and while testosterone levels did not differ, African-American men had significantly higher serum estradiol levels than Caucasian or Mexican-American men, a difference that was most pronounced in early and mid-adulthood [29]. This is highly significant in that African-American men have a twofold higher rate of prostate cancer than Caucasian-American men, as well as a greater prostate cancer risk than Hispanic males. Studies on pre- and peri-natal exposure to estrogens have also raised concerns about their carcinogenic potential. Some authors have suggested that the higher incidence of prostate cancer among African-American men is partly due to in utero exposure to maternal estrogens since African-American women have higher circulating estrogen concentrations during pregnancy than Caucasian women [30,31], although gestational androgen levels are also elevated.

Animal models of prostate cancer have demonstrated that, at least in rats, estrogen is a necessary, if not sufficient, condition for prostate carcinogenesis. Although rats do not naturally develop prostate cancer, it can be induced in Noble rats by combined treatment with estradiol and testosterone, with testosterone playing a supportive role since androgen supplementation alone is insufficient to drive carcinogenesis [32-34]. A recent review by Bosland reinforced this notion, citing an incidence of prostate cancer induction in Noble rats of $100 \%$ with testosterone and estrogen, but only $40 \%$ with testosterone alone.

Dihydrotestosterone, which is not aromatized to estrogen as testosterone is, could induce cancer in only $4 \%$ of rats [35]. In addition, rodent studies have consistently demonstrated increased susceptibility to prostate cancer in mice or rats exposed to DES or pharmacologic levels of estradiol-17 $\beta$ in utero or neonatally [36-39]. While rodent models offer a chance to study the developing reproductive system following estrogenic exposures, the possibility of species-specific findings limits their applicability to humans. New emerging models offer the opportunity to study the effects of estrogen on undifferentiated human prostate tissue. The first such model is the isolation of adult prostate stem or progenitor cells [40-44]. Although only present at a low frequency in the epithelial cell population, these cells have the ability to differentiate into three different epithelial cell types [45] and to survive and form spheroids in 3D matrigel culture [46-48], permitting their isolation from adult epithelial cell populations. These 'prostaspheres' can begin to differentiate on their own with extended culture and form branched-like structures with epithelial bilayers and lumens [49]. Importantly, recent results from our laboratory have found that undifferentiated prostasphere cells express robust levels of ERs, including ER $\alpha$, ER $\beta$ and G-protein-coupled receptor (GPR)30, indicating that prostate progenitor cells may be direct estrogen targets [49]. Furthermore, the normal prostate progenitor cells exhibit a proliferative response to $1 \mathrm{nM}$ 
estradiol-17 $\beta$, suggesting that estrogen may regulate stem/progenitor cell self-renewal in the prostate gland. This new model thus provides a novel opportunity to investigate the effects of estrogenic exposure during human prostate differentiation.

The second emerging model is human chimeric tissue grafts. Taylor et al. first reported the formation of human prostate tissue by combining human embryonic stem cells with rat urogenital mesenchyme (UGM) and implanting it as a tissue graft under a mouse renal capsule with the formation of a normal prostate-like structure after 1-2 months [50]. We have recently reported a similar model using prostate stem/progenitor cells isolated from normal human organ donors, which generate normal human prostate-like tissue when combined with rat UGM as renal grafts in nude mice. Exposure of these engrafted mice to elevated testosterone and estrogen for 2-4 months resulted in the induction of prostate cancer over time, progressing from normal histology to epithelial hyperplasia, prostate intraepithelial neoplasia (PIN) and prostate cancer with local renal invasion [49]. An example of a locally invasive adenocarcinoma seen in a xenograft after explantation is shown in Figure 1. The tumor was induced using estrogen plus testosterone supplementation after implanting human epithelial progenitor cells and rat UGM under the renal capsule of a nude mouse. This is the first direct evidence with normal human prostate epithelial cells that estrogens in an androgen-supported milieu are carcinogens for human prostate epithelium, capable of driving prostate cancer initiation and progression to adenocarcinoma. This new model allows the study of normal human prostate tissue development and differentiation, as well as providing a format to interrogate pathways involved in prostate hormonal carcinogeneis with the aim of uncovering therapeutic interventions.

For all the observations on the changes in prostate tissues affected by estrogens as well as the associated risk of cancer, relatively little is known about the exact mechanisms by which these compounds predispose to or directly cause prostate cancer. Proposed mechanisms include epigenetic modifications, direct genotoxicity, hyper-prolactinemia, immunotoxic or inflammatory changes, and prostatic ER-mediated changes. While these mechanisms are probably interrelated and should by no means be considered mutually exclusive, the following sections will examine evidence for estrogen's role in prostate cancer by focusing on each of these potential mechanisms individually. Their interrelationships are depicted graphically in Figure 2, with selected references supporting each pathway.

\section{Estrogen imprinting \& epigenetic modifications}

There is reason to believe that some of the effects of estrogen on the prostate gland are the result of developmental exposures that predispose to prostate disease later in life, fitting into the emerging paradigm on the fetal basis of adult disease. A classic example is in utero exposure to DES, which has been linked to increases in breast and vaginal cancer of exposed offspring, although adult DES exposure presents limited risk for these cancers [51-55]. The prostate gland is similarly dependent upon steroid hormones, and imbalances in these hormones during development can result in abnormalities in growth and differentiation [56]. For example, in utero DES exposure has been associated with an increased rate of structural abnormalities of the prostatic utricle in newborn sons [56], while elevated maternal estrogen levels during pregnancy have been associated with increased prostate cancer risk in humans [57]. In rodents, DES exposure during the perinatal period predisposes the offspring to prostate cancer [36]. While it remains to be investigated if the overall risk of developing prostate cancer is increased in humans after in utero exposure to DES as exposed sons are just now entering the typical age of prostate cancer risk, the earlier onset of disease as seen with breast cancer in DES-exposed daughters has not been demonstrated with prostate cancer. 
Rodent models are useful for studying estrogenic imprinting since their prostate gland undergoes morphogenesis and differentiation postnatally [58], as opposed to the human gland, which is fully formed and differentiated at birth. Studies from our laboratory using the rat model have shown that brief perinatal exposure to high doses of estrogens results in permanent changes, including alterations in gene expression and cell signaling [58,59], a process known as estrogenization or estrogen imprinting. These animals go on to develop inflammation, prostatic hyperplasia and PIN, considered the precursor lesion for prostate cancer [60]. The ability of this early estrogenic exposure to predispose, rather than cause, cancer is best demonstrated by a 'two-hit' model of prostate carcinogenesis in Sprague Dawley rats. Neonatal rats were briefly exposed to $17 \beta$-estradiol or the environmental estrogen bisphenol A (BPA) at serum concentration levels similar to those measured in humans - considered the first hit - followed by a second exposure to estradiol in adulthood to mimic increased estrogen levels observed in aging men [33,61]. While the low-dose estrogen or BPA exposures alone had no effect on the rate of premalignant PIN lesions in the prostate lobes, they markedly increased the susceptibility of the adult prostate to highgrade PIN lesions induced by adult estradiol, increasing the incidence from $40 \%$ in control rats to $100 \%$ in those exposed neonatally to estrogens $[62,63]$. Thus, the developmental exposure appears to 'prime' the prostate, resulting in increased carcinogenesis with subsequent exposures later in life.

Since early-life estrogenic exposure does not appear to drive carcinogenesis by itself, it is possible that it increases susceptibility by silencing tumor-suppressor genes, augmenting expression of tumor-promoter genes or otherwise reducing the tissue's resistance to malignant transformation. Evidence from our rodent model of prostate neonatal estrogenization has shown lifelong alterations in DNA methylation of specific genes, suggesting an epigenetic basis for estrogen imprinting $[62,64]$. DNA and histone methylation are mechanisms of epigenetic gene silencing or activation that can permanently alter gene expression since they are mitotically heritable and can be maintained over the lifespan. Epigenetic alterations have been associated with the initiation of multiple cancers $[65,66]$, including prostate cancer, in which promoter $\mathrm{CpG}$ island or histone modifications have been identified that result in silencing of tumor-suppressor genes [62,67-71]. Of interest, these epigenetic alterations are reversible through DNA demethylating agents such as 5-azacytidine and histone modifiers, causing transcription of these genes to resume, with some identifiable phenotypic changes $[69,70]$. In this context, it is noteworthy that alterations in DNA methylation have been reported in human reproductive tissues developmentally exposed to DES [72-74]. Thus, hypermethylation of the promoter regions of tumor-suppressor genes or hypomethylation of tumor-promoter genes is one potential mechanism by which developmental estrogens may predispose to prostate cancer later in life.

\section{Direct genotoxicity}

Although initial studies of estrogen at pharmacologic concentrations suggested that estrogens only have weak, if any, direct mutagenic properties [75-79], more recent studies using lower, physiologic concentrations have shown multiple direct genetic lesions that appear to be inducible by estrogens or their metabolites. Specifically, estrogen-induced changes have been identified in animal or human tissue studies consisting of aneuploidy [80-87], chromosomal aberrations [84,88,89], point mutations [79,90,91] or microsatellite instability [91]. In one study in the human mammary carcinoma cell line MCF-7, concentrations of estrone and $\beta$-estradiol in the nanomolar range were able to induce singlestranded DNA breaks by the Comet assay and micronuclei after only $24 \mathrm{~h}$ of exposure [92]. Although these studies were primarily performed in nonprostatic tissue, they highlight potential mechanisms of genotoxicity. In rat prostates, single-stranded DNA breaks and lipid 
peroxidation have been identified in in vivo rat prostate models [32] following adult exposure to estrogens, which supports the proposal that estrogen genotoxicity may play a role in prostate carcinogenesis.

Considerable research on the carcinogenic actions of estrogens in breast tissue as well as other female reproductive tract organs has identified catechol-estrogen formation as a significant factor in carcinogenesis [93]. The phase I enzymes CYP1A1 and CYP1B1 catalyze the conversion of estradiol to 2-hydroxyestradiol and 4-hydroxyestradiol, respectively, in end organs that express these enzymes. Subsequently, the 2- and 4hydroxyestradiols can be rapidly oxidized to 2,3- and 3,4-semiquinones and quinones, respectively, which are capable of forming DNA adducts, leading to DNA damage including single- and double-stranded DNA breaks. In general, 2-hydroxyestradiol is considered less damaging, while 4-hydroxyestradiol and its respective quinone have greater genotoxicity. To maintain intracellular homeostasis, the phase II enzyme, catechol- $O$-methyl transferase converts these metabolites to 2- and 4-methoxyestrone, respectively, which are rapidly excreted. Importantly, while the human prostate expresses these enzymes [94], estrogens are capable of markedly increasing CYP1B1 expression in a variety of tissues. Work in our laboratory determined that the adult prostates of rats treated neonatally with high-dose estradiol expressed sixfold higher levels of CYP1B1 and twofold more catechol- $O$-methyl transferase than oil-treated controls, indicating permanent estrogen metabolic stress [Prings GS, Unpublished Data]. As previously described, CYP1B1 is also differentially expressed in the zones of the prostate, with higher levels of both protein and mRNA in the more cancerprone peripheral zone $[27,28]$. It is noteworthy that polymorphisms have been identified in the CYPIB1 gene that affect its catalytic activity, and African-Americans have the more potent Leu $432 \mathrm{Val}$ at a 0.75 frequency compared with 0.43 in Caucasians and 0.17 in the Chinese population [95]. Furthermore, in a small case-controlled study, 34\% of Caucasian men with prostate cancer $(\mathrm{n}=50)$ were homozygous for the Leu432 Val polymorphism, while only $12 \%$ of matched control subjects $(n=50)$ had this genotype [95]. Together, these limited findings support the notion that genotoxic estrogen metabolites may contribute to prostate carcinogenesis.

\section{Hyperprolactinemia}

Chronic estrogen exposure increases circulating prolactin levels in adult humans, and has been used as a model for inducing hyper-prolactinemia in rodents [96]. This effect on prolactin levels holds true for both endogenous estrogens as well as xenoestrogens [97]. Although prolactin levels had been considered to be of little consequence in oncology for many years, recent evidence of the role of prolactin in the development of breast and prostate cancer has changed this view. The proliferative effects of prolactin are well known, and these effects have been cited as a factor that both supports tumor growth and induces chemoresistance in multiple cancers [98]. Two recently identified mechanisms - locally produced prolactin and genetic variants of the prolactin receptor - have been championed as potential factors in prolactin's role in prostate cancer [99]. Specifically in human prostate epithelial cells, autocrine prolactin appears to be responsible for activation of Stat5 [100], an important survivability factor for prostate cancer cells associated with hormone resistance, higher histological grade and earlier recurrence, possibly through interaction with the androgen receptor [101]. Whether this locally produced prolactin is under estrogen regulation, as is the case in the posterior pituitary, is presently unclear and requires further investigation.

Evidence also exists for the role of circulating endogenous prolactin, which is under estrogenic control, in driving prostate cancer. It was identified as a survival factor for androgen-deprived prostate tissue in rats [102], and in the presence of androgen can induce 
enlargement and inflammation of the lateral rat prostate without any histological changes on ventral and dorsal lobes [103]. These histological changes are accompanied by overexpression of Bcl-2, which may inhibit apoptosis [104]. As will be discussed in the next section, inflammation of the prostate has been associated with the development of prostate cancer in numerous epidemiological and ontological studies. Importantly, several, but not all, of the gene-expression and inflammatory changes induced by estrogen in the prostate appear to be mediated by prolactin produced by the pituitary [105]. In one recent study, 2504 genes were identified as having their expression significantly altered in rat lateral prostate by treatment with testosterone and estradiol. Of these, $80 \%$ were blocked by cotreatment with the antiestrogen ICI and bromocriptine, which blocks production of prolactin in the pituitary gland [106]. However, only $10 \%$ of these changes could be blocked by ICI alone, suggesting that not only does prolactin play an important role in mediating these changes, but also that centrally produced, rather than local, prolactin is involved. These findings have led some to suggest that blockade of the prolactin receptor is a potential therapy for both breast and prostate cancer [98]. Indeed, in a transgenic mouse model, prolactin antagonism has been shown to block prostate tumorigenesis [107].

\section{Inflammation \& immunogenic changes}

One of the histopathologic hallmarks of estrogen-treated prostate tissue is chronic inflammation. Exogenously administered estrogen has resulted in numerous prostatic changes including loss of basal/apical orientation, and relative increase in stromal elements and inflammatory cell infiltrates $[38,108,109]$. Chronic immune cell infiltrates also play a role in prostate dysplasia of adult rat prostates after neonatal estrogen exposure, with an increased prevalence of $\mathrm{CD}^{+}$and $\mathrm{CD} 8^{+} \mathrm{T}$ cells as well as macrophages in the adult tissues long after estrogen exposure, suggesting an estrogenic priming of the immune system [105]. These inflammatory effects can be partially, but not completely, reduced using bromocriptine to block hyperprolactinemia, suggesting estrogen-induced prolactindependent and -independent components [105]. Using a murine model with aromatase gene overexpression to increase endogenous estrogen levels, Ellem $e t$ al. described these inflammation-related prostatic changes in detail [110]. Mice with overexpressed aromatase had smaller prostates than controls at puberty, with a significant increase in mast cell numbers. By 40 weeks of age, inflammatory changes were present, accompanied by increases in mast cell, macrophage, neutrophil and T-lymphocyte numbers. In another study using adult Wistar rats, inflammatory signaling began soon after estrogen exposure, with upregulation of IL- $1 \beta$, IL-6, macrophage inflammatory protein 2 and inducible nitric oxide synthase transcripts after only 4 days treatment with injected estradiol [111]. The significance of estrogen-induced inflammation is the association of immune cells and cytokines with cancer. Chronic inflammation has been associated with a number of malignancies, including prostate cancer. By some measures, infection and inflammation have been linked to as many as 15-20\% of all cancers in humans [112-114]. Several studies have now indicated that prostate cancer may fall into that category, with clear associations drawn between prostate cancer and prostatitis $[111,115,116]$. Evidence of this in humans includes the finding of activated inflammatory cells next to areas of prostate cancer and premalignant lesions [112] and an increase in the incidence of prostate cancer in men with a history of prostatitis [117]. Prostate inflammation often displays epithelium which is atrophic but paradoxically expresses increased proliferation and decreased apoptosis [118]. These findings have been termed 'proliferative inflammatory atrophy' and are considered by some to be a potential precursor lesion for high-grade PIN (HGPIN) and prostate cancer based on the proliferation and tendency to be found in the peripheral rather than transition zone of the prostate, as is the case with prostate cancer [119]. 
Proposed mechanisms of inflammation-induced cancer include oxidative stress with free radical formation and subsequent DNA damage [120-122]. In addition, several inflammatory cytokines and prostaglandins, including IL-1 $\alpha$ and IL-8, are associated with angiogenesis [123-125], a necessary process in the growth of most tumors. These multiple pathways by which inflammation can lead to cancer formation make it an attractive target for research in cancer prevention. Indeed, multiple recent publications have investigated the association of aspirin or other nonsteroidal anti-inflammatory drugs with prostate cancer risk or treatment. A meta-analysis of studies conducted prior to June 2008, including 24 studies and 24,230 patients, revealed a small but statistically significant reduction in the risk of developing prostate cancer with a pooled odds ratio of 0.83 [126]. In the past year, at least five large studies have been published on this topic, with conflicting results. One large prospective cohort with a total of 51,529 patients revealed a decrease in the risk of developing prostate cancer of nearly $10 \%$ with chronic aspirin use [127], while another cohort study with 34,132 patients showed no significant difference [128].

\section{Receptor-mediated changes \& hormonal dysregulation}

Estrogen's primary hormonal functions are mediated through estrogen-specific receptors, of which there are several types with possibly opposing functions. These different receptors are distributed in varying expression levels in human tissues with the highest expression observed in estrogen-sensitive tissues [129]. Importantly, multiple ERs are localized in prostate tissues and their activation has been associated with a number of phenotypic changes in vitro and in vivo. A significant amount of evidence has accumulated demonstrating that direct estrogen signaling pathways within prostate cells play an important role in the development of the prostate gland and possibly in the development of cancer [130-135].

Most hormonally regulated effects of estrogens have been attributed to the nuclear steroid receptors ER $\alpha$ and ER $\beta$ [136]. Recent evidence has shown that rapid membrane-initiated signaling of estrogens can also occur through liganding of ER $\alpha$ or ER $\beta$ localized to the cell membrane that in turn initiates downstream kinase cascades [137], although these signaling pathways have not yet been well characterized in prostate cells. In addition, another binding moiety localized to cell membranes and activated by estrogens has been identified and named GPR30 [138]. These three proteins have tissue-dependent distribution and different effects on cell phenotype and activity. As discussed later, the activity of endogenous estrogens or dysregulation by exogenous estrogens on any or all of these receptors may play a role in prostate cancer development and/or progression. The demonstrated effects of each receptor on prostate tissue and disease are summarized in Table 1.

Estrogen receptor- $\alpha$ was the first ER to be described and is sometimes referred to as the 'classical' ER. In the prostate gland, it is primarily localized to the stroma and basal cell layer, which contains prostatic stem cells capable of proliferation [135,139]. In the common rodent model of prostate cancer utilizing testosterone plus estrogen to induce PIN and cancer, the ER $\alpha$ is clearly essential, as knockout mice that lack the ER $\alpha$ do not develop high-grade PIN or prostate cancer, while ER $\beta$-knockout mice do, as do wild-type mice [25]. Similarly, neonatal exposure to DES requires ER $\alpha$ since ER $\alpha$-knockout mice lack the estrogenized phenotype while ER $\beta$-knockout mice exhibit full estrogenization [140]. In human tissue, ER $\alpha$ mRNA and protein have both been detected in HGPIN lesions [135]. Moreover, the activity of these receptors can be inferred from the presence of progester-one receptors in the lesions and the estrogen-inducible protein $\mathrm{pS} 2$. The progesterone receptor is inducible by estrogen and is an important marker for a functional ER. It can be found in 33$58 \%$ of primary prostate tumors, with an expression level correlated with ER $\alpha$ mRNA and stronger, more consistent expression in metastatic and androgen-insensitive lesions [141]. 
PS2 was expressed in HGPIN lesions as well as benign acini adjacent to cancerous lesions in radical prostatectomy specimens, but was consistently lacking in tissue obtained from individuals without histologic evidence of disease [142], suggesting ER $\alpha$ activity in a 'field effect' around these lesions. In addition, much of the inflammation induced in mouse prostates - which may play a role in prostate cancer as previously described - appears to be mediated by ER $\alpha[140,131]$. In clinical studies, blocking ER $\alpha$ with toremifene caused a nearly $50 \%$ reduction in the rate of biopsy-detected prostate cancer in men with high-grade PIN on biopsy 12 months earlier [143]. However, actual ER $\alpha$ protein expression is typically only detectable in high-grade (Gleason 4 or 5) cancerous lesions [135]. Overall, this evidence appears to suggest that ER $\alpha$ is essential for at least one model of prostate cancer formation in rodents, and that in humans, it is at a minimum circumstantially associated with disease formation and progression, and may possibly be a target for chemoprevention.

The second nuclear ER, ER $\beta$, was first cloned in 1996 from a rat prostate cDNA library [144]. Using different antibodies, this receptor is primarily localized to prostatic epithelium, although some stromal cells can express ER $\beta$, albeit at lower levels than the epithelium $[139,145,146]$. In the developing human prostate, it appears to be the predominant receptor in both stromal and epithelial cells [146]. In contrast to ER $\alpha, E R \beta$ appears to be antiproliferative and possibly even tumor suppressive. Its relatively high affinity for phytoestrogens compared with ER $\alpha$ [144] may in part explain the anticancer properties attributed to genistein and other soy isoflavones. These properties and their interaction with the ER $\beta$ receptor were highlighted in a case-control study conducted in 2100 Swedish participants, which found a significant multiplicative interaction between dietary phytoestrogen intake and specific single-nucleotide polymorphisms of the $E R \beta$ gene in the reduction in risk of prostate cancer [147]. In this study, subjects with the identified singlenucleotide polymorphism and the highest quartile in total phytoestrogen intake showed a 0.43 odds ratio for developing prostate cancer when compared with the lowest quartile. Subjects who were homozygous for the wild-type receptor showed no significant dependence on phytoestrogens. The association of ER $\beta$ with anti-tumor signaling is indicated from immunohistochemical studies revealing that although ER $\beta$ is present in the majority of localized prostate cancer, it is reduced or absent in $40 \%$ of hormone-refractory disease and HGPIN [145]. Other studies have confirmed an inverse correlation between ER $\beta$ expression and Gleason score, with decreasing ER $\beta$ expression attributed to hypermethylation of the gene promoter [148,149]. It has recently been reported that high Gleason grade cancers exhibit mesenchymal characteristics, including increased hypoxiainducible factor- $1 \alpha$, vimentin and VEGF expression, a phenomenon known as epithelialmesenchymal transition (EMT) [150]. These changes can be induced in androgen-sensitive or -resistant cells by exposure to hypoxic conditions or TGF- $\beta$, which also diminishes ER $\beta$ levels without affecting ER $\alpha$. Conversely, silencing of ER $\beta$ with short hairpin RNA was sufficient to induce EMT. Moreover, EMT could be prevented and epithelial phenotype preserved using $3 \beta$-androstandiol, a purported ER $\beta$ ligand [150]. Thus, ER $\beta$ appears to play a role in preventing some of the changes associated with more aggressive local prostate cancer. Furthermore, a recent study using murine models, as well as human prostate cancer xenografts and cell lines, demonstrated that ER $\beta$-specific agonists could drive prostate stromal and epithelial cell apoptosis, an event that was dependent on TNF- $\alpha$ signaling [151]. Importantly, this action was androgen independent, thus indicating potential therapeutic benefit in castration-resistant prostate cancers.

G-protein-coupled receptor 30 was first identified as a novel membrane-bound protein in 1998 [138], but has only recently been investigated primarily as a protein that mediates estrogen signaling in multiple cell types [152-160]. GPR30 displays similar affinity to estradiol- $17 \beta$ with $E R \alpha$ and $E R \beta$ in the 3-6 nM range, with almost no affinity for estradiol-17 $\alpha$ corticosteroids or testosterone [161]. It is distinct from the two known ERs, 
ER $\alpha$ and ER $\beta$, not only in its structure, which is not a modular transcription factor, but also in that it is unaffected by standard anti-estrogens such as ICI [162]. In breast cancer, GPR30 overexpression has been positively associated with tumor size, the presence of distant metastases, increased human EGFR-2/neu expression [163] and aggressive inflammatory disease [164]. In many cell types, there is evidence that GPR30 collaborates with membrane $\mathrm{ER} \alpha$ and requires the latter receptor to generate downstream signaling cascades [137]. Part of the mechanism by which GPR30 stimulates disease progression appears to be through stimulation of cancer-associated fibroblast (CAF) proliferation and migration [165]. CAFs are associated with disease progression [166-168] and are stimulated by physiologic doses of estradiol. These fibroblasts express GPR30, but not ER $\alpha$ or ER $\beta$, and silencing GPR30 with short hairpin RNA blunts the stimulatory effect of estradiol on CAFs [165]. GPR30 has also been shown to promote proliferation in thyroid [161], endometrial [157] and ovarian [160] cancers. In contrast to these findings, GPR30 appears to cause growth inhibition in prostate cancer cells in vitro and in xenografts in vivo [169]. Using siRNA and the GPR30 agonist G-1, the authors demonstrated that GPR30 activation resulted in cell-cycle arrest of PC- 3 cells at the G2 phase, which occurred via sustained activation of Erk $1 / 2$ and ultimately upregulation of p21. Interestingly, GPR30 has also been shown to induce Erk1/2 activation in breast cancer cells via activation by BPA [162]. The fact that this protein can mediate growth in one cell type and inhibition in another through pathways that are at least initially identical highlights the complexity of the estrogen signaling system.

Further differentiation of the roles of each receptor type, and possibly their splice variants, will depend on our ability to activate or inhibit individual receptor types without affecting the state of the other signaling mediators. Significant effort has been made in the development and modification of compounds that are selective agonists or antagonists for specific ER molecules and are referred to as selective estrogen receptor modulators (SERMs). Given the known functions of the receptors, there is particular interest is the development of ER $\alpha$-selective antagonists [170] and ER $\beta$ selective agonists [171]. Some anti-estrogen SERMs have been evaluated for prostatic responses in animal and cell culture models and as a few clinical trials and were recently summarized in a review by Bonkhoff and Berges [130]. Briefly, the antiestrogens tamoxifen, raloxifene, trioxifene, ICI and toremifene inhibited cancer cell growth and/or induced cancer cell apoptosis in vitro or in vivo [172-178]. One recent study of particular note demonstrated that ER-selective agonists exhibited differential regulation of the oncogenic TMPRSS2-ERG fusion gene in prostate cells, with ER $\alpha$ agonists stimulating expression and ER $\beta$ agonists inhibiting the oncogene expression [179]. In clinical trials, however, the results have been less promising. Tamoxifen, which is a mixed agonist/antagonist and has significant activity at both ER $\alpha$ and $\mathrm{ER} \beta$, was well tolerated but demonstrated limited activity in 30 patients with hormonerefractory prostate cancer [180]. The pure anti-estrogen ICI, which antagonizes both ER $\alpha$ and ER $\beta$, also produced no response in 20 patients with recurrence after androgendeprivation therapy [177]. Only toremifene, an ER $\alpha$ antagonist, has shown real promise to date. As described previously, it decreases the incidence of prostate cancer detected in men on biopsy 12 months following a previous biopsy with high-grade PIN [143]. In the transgenic adenocarcinoma of mouse prostate (TRAMP) model, toremifine appeared to be a powerful chemopreventive agent for prostate cancer. Untreated TRAMP mice develop HGPIN by 17 weeks of age, whereas none of the toremifine-treated mice exhibited these lesions. At 30 weeks of age, only $28 \%$ of TRAMP mice treated with toremifene had histologic evidence of prostate cancer, compared with $100 \%$ of placebo-treated mice; at 33 weeks, only $43 \%$ had tumors, whereas all of the placebo group died [178]. Although toremifine has not yet been proven to delay or prevent disease progression in humans, it appears to improve bone mineral density and lipid profiles in men on androgen-deprivation therapy [181,182]. The fact that these positive results come from an ER $\alpha$ selective antagonist as opposed to a ligand that affects both ER $\alpha$ and ER $\beta$ highlights the need for the 
continued development of next-generation SERMs to differentiate the function of receptor subtypes. The picture is further complicated by the existence of multiple splice variants of each receptor. Although most studies use primers and ligands that do not distinguish splice variants from full-length ERs, evidence is growing that these variants play important roles in both normal estrogen signaling and disease susceptibility [183]. In particular, the ER $\alpha$ splice variant $E R \alpha \Delta 5$ demonstrated increased levels of expression by reverse-transcriptase PCR in tissue adjacent to tumor when compared with benign tissue [184].

\section{Phytoestrogens \& prostate health}

In addition to their ability to influence testosterone levels and bone mineral homeostasis, it has been proposed that natural estrogens and dietary estrogen analogs may be protective against the development of prostate cancer, rather than simply being a treatment for prostate disease. This has resulted in extensive research into the anticancer properties of phytoestrogens, and in particular soy isoflavones such as genistein. The initial evidence for this was epidemiological, with the age-standardized incidence of prostate cancer in Japan, where soy consumption is high, being 12.6 per 100,000 men as compared with 119.9 in the USA [185]. However, among second- and later-generation Japanese populations living in the USA, the incidence of prostate cancer is much closer to that of the general US population, suggesting an environmental or dietary cause for the difference observed. Subsequent studies focusing on soy and its associated proteins investigated the dietary impact on the risk of prostate cancer, with a large meta-analysis suggesting that both fermented and nonfermented soy were protective against cancer, with odds ratios of 0.69 and 0.75 , respectively [186]. While tofu was the only individual food showing a protective effect, the phytoestrogens genistein and daidzein were also associated with a lower risk of prostate cancer.

Further evidence of the protective effect of genistein can be gleaned from studies using rodent models and human cell lines. In two separate studies, Mentor-Marcel and colleagues investigated the effects of genistein on the progression of prostate cancer in the TRAMP mouse model of prostate cancer $[187,188]$. When dietary genistein was used to elevate mouse serum genistein to levels comparable to that of Asian men, the rate of poorly differentiated adenocarcinoma decreased in a dose-dependent manner [187], while survival improved as a function of decreased tumor burden [188]. Recent studies using a rat hormonal carcinogenesis model have shown that a soy isoflavone mixture that includes genistein and diazein is able to protect against carcinogenesis in the dorsolateral and anterior prostate lobes [189]. In vitro studies revealed that genistein inhibited growth of two prostate cancer cell lines alone or in combination with selenium [190]. The treatment also induced apoptosis through caspase-dependent pathways, and reduced expression of matrix metalloproteinase 2 , which has been associated with active invasion and metastases.

While the exact mechanisms of genistein's protective effects have not been elucidated, many current studies are focused on changes in DNA methylation and other mechanisms that alter gene and protein expression. The promoter $\mathrm{CpG}$ islands of many tumor-suppressor genes become methylated in several prostate cancer cell lines, resulting in silencing of their transcription. Treatment with genistein and other soy phytoestrogens resulted in demethylation of the glutathione- $S$-transferase $\mathrm{P}$ and epoxide hydrolase receptor $\mathrm{B} 2$ gene promoters, with parallel rises in their protein expression by immunohistochemistry [69]. This is significant since glutathione- $S$-transferase $\mathrm{P}$, a $\pi$-class glutathione- $S$-transferase, is silenced by promoter hypermethylation in prostate basal cells and is one of the known early events in human carcinogenesis due to the loss of its protective antioxidant capacity [191]. A similar study in prostate cancer tissues as well as cell lines demonstrated that the tumorsuppressor B-cell translocation gene 3 is silenced in prostate cancer, with re-expression 
induced by demethylation with either genistein or 5-azacytidine [70]. An alternative proposed mechanism of action is through changes in histone rather than promoter modification. Several tumor-suppressor genes (PTEN, CYLD, p53, FOXO3a and SIRT1) were identified that are silenced in prostate cancer cell lines, but have unmethylated promoter regions. Expression of these tumor-suppressors was restored after treatment with genistein, and this was found to be associated with either methylation or deacetylation of histone H3-lysine 9 [71]. Finally, there is ample evidence that genistein induces at least some of its changes through ER-mediated pathways, in particular ER $\beta$, for which it has higher affinity. Apoptosis-inducing effects of genistein on T-cell leukemia cells can be blocked by the anti-estrogen ICI [192], and other observed effects of genistein appear to be blocked by silencing of the ER $\beta$ in gerbil neurons [193] or PC-3 prostate cancer cells [194]. As described previously, the ER $\beta$-mediated effects of phytoestrogens may partly depend on specific $E R \beta$ gene polymorphisms [147].

\section{Expert commentary}

Our understanding of estrogen's function in the pathogenesis, prevention and treatment of prostate cancer is still evolving. Although androgens are clearly involved in the progression of prostate cancer and anti-androgen therapy will probably remain the treatment of choice for metastastic disease for the foreseeable future, it is equally clear that androgens are only one side of the story. At least in rats, testosterone alone is necessary, but not sufficient, for the development of prostate cancer. It is only with the addition of estrogen that cancer can be reliably induced. In vivo and in vitro studies have identified multiple mechanisms of potential carcinogenesis, including direct genotoxicity, epigenotoxicity, hyperproloctinemia, chronic inflammation and prostatic ER-mediated changes that are in addition subject to disruption by environmental estrogens. Moreover, ample evidence for estrogen's role in the development of human prostate cancer exists in the form of epidemiological data and associations between inflammation and cancer, which parallels findings in rodent prostates. The true role of estrogen in prostate cancer development and progression is probably complex and multifactorial, incorporating more than one of the mechanisms already described and with interplay between them.

\section{Five-year view}

Given the relatively low rate of mutations caused by estrogen at physiologic concentrations and the few consistent mutations identified in clinical prostate cancer, it is likely that future breakthroughs will be in the field of gene silencing or activation through epigenetic effects or hormonal dysregulation. The use of new models such as stem cells, prostaspheres and chimeric tissues will allow well-controlled investigations into the effects of estrogen on human prostate development and carcinogenesis. Finally, the development of new selective ER modulators offers exciting opportunities to examine the effect of individual ER subtype activation or antagonism with therapeutic potential. Further elucidation of the roles of the different receptors and their splice variants and polymorphisms may direct future laboratory research and ultimately clinical therapeutic intervention in the form of treatment or prevention by dietary modification or pharmacologic treatment.

\section{References}

Papers of special note have been highlighted as:

- of interest 
1. Huggins C, Hodges CV. Studies on prostate cancer: I. The effect of castration, of estrogen and of androgen injection on serum phosphatases in metastatic carcinoma of the prostate. Cancer Res. 1941; 1:293-297.

2. Huggins C. Endocrine control of prostate cancer. Science. 1943; 97:541-544. [PubMed: 17773799]

3. Wibowo E, Schellhammer P, Wassersug RJ. Role of estrogen in normal male function: clinical implications for patients with prostate cancer on androgen deprivation therapy. J Urol. 2010; 185:17-23. [PubMed: 21074215]

4. Citrin DL, Resnick MI, Guinan P, et al. A comparison of Zoladex and DES in the treatment of advanced prostate cancer: results of a randomized, multicenter trial. Prostate. 1991; 18:139-146. [PubMed: 1826048]

5. Dal Pra A, Cury FL, Souhami L. Combining radiation therapy and androgen deprivation for localized prostate cancer - a critical review. Curr Oncol. 2010; 17(5):28-38. [PubMed: 20975876]

6. Kim HS, Freedland SJ. Androgen deprivation therapy in prostate cancer: anticipated side-effects and their management. Curr Opin Support Palliat Care. 2010; 4(3):147-152. [PubMed: 20592607]

7. Geier R, Adler S, Rashid G, Klein A. The synthetic estrogen diethylstilbestrol (DES) inibits the telemorase activity and gene expression of prostate cancer cells. Prostate. 2010; 70:1307-1312. [PubMed: 20623632]

8. Montgomery B, Nelson PS, Vessella R, Kalhorn T, Hess D, Vorey E. Estradiol suppresses tissue androgens and prostate cancer growth in castration resistant prostate cancer. BMC Cancer. 2010; 10:244. [PubMed: 20509933]

9. Post-menopausal estrogen therapy. IARC Mongr Eval Carcinog Risks Hum. 1992; 72:399-530.

10. International Agency for Research on Cancer. Monographs on the evaluation of carcinogenic risks to humans. Vol. 7. IARC; Lyon, France: 1987. p. 280-285.

11. International Agency for Research on Cancer. Monographs on the evaluation of carcinogenic risks to humans: hormonal contraception and postmenopausal hormone therapy. Vol. 72. IARC; Lyon, France: 1999.

12. Greenwald P, Caputo TA, Wolfgang PE. Endometrial cancer after menopausal use of estrogens. Obstet Gynecol. 1977; 50:239-243. [PubMed: 876565]

13. Siiteri, PK.; Nisker, JA.; Hammond, GL. Hormonal basis of risk factors for breast and endometrial cancer. In: Iacobelli, S.; King, RJB.; Lindner, HR.; Lippman, ME., editors. Hormones and Cancer. Raven Press; NY, USA: 1980. p. 499-505.

14. Feigelson HS, Henderson BE. Estrogens and breast cancer. Carcinogenesis. 1996; 17:2279-2284. [PubMed: 8968038]

15. Bernstein L. The epidemiology of breast cancer. LOWAC J. 1998; 1:7-13.

16. Barrett-Connor E, Garland C, McPhillips JB, Khaw KT, Wingard DL. A prospective, populationbased study of androstenedione, estrogens, and prostatic cancer. Cancer Res. 1990; 50(1):169-173. [PubMed: 2293551]

17. Modugno F, Weissfeld JL, Trump DL, et al. Allelic variants of aromatase and the androgen and estrogen receptors: toward a multigenic model of prostate cancer risk. Clin Cancer Res. 2001; 7:3092-3096. [PubMed: 11595700]

18. Gann PH, Hennekens CH, Ma J, Longcope C, Stampfer MJ. Prospective study of sex hormone levels and risk of prostate cancer. J Natl Cancer Inst. 1996; 88:1118-1126. [PubMed: 8757191]

19. Eaton NE, Reeves GK, Appleby PN, Key TJ. Endogenous sex hormones and prostate cancer: a quantitative review of prospective studies. Br J Cancer. 1999; 80:930-934. [PubMed: 10362098]

20. Platz EA, Leitzmann MF, Rifai N, et al. Sex steroid hormones and the androgen receptor gene $\mathrm{CAG}$ repeat and subsequent risk of prostate cancer in the prostate-specific antigen era. Cancer Epidemiol Biomarkers Prev. 2005; 14:1262-1269. [PubMed: 15894683]

21. Wiren S, Stocks T, Rinaldi S, Hallmans G, et al. Androgens and prostate cancer risk: a prospective study. Prostate. 2007; 67:1230-1237. [PubMed: 17562541]

22. Mohler JL, Gregory CW, Ford OH, et al. The androgen axis in recurrent prostate cancer. Clin Cancer Res. 2004; 10:440-448. [PubMed: 14760063]

23. Ellem SJ, Schmitt JF, Pedersen JS, Frydenberg M, Risbridger GP. Local aromatase expression in human prostate is altered in malignancy. J Clin Endocrinol Metab. 2004; 89:2431-2441. 
24. Montgomery RB, Mostaghel EA, Vessella R, et al. Maintenance of intratumoral androgens in metastatic prostate cancer: a mechanism for castration-resistant tumor growth. Cancer Res. 2008; 68:4447-4454. [PubMed: 18519708]

25. Ricke WA, McPherson SJ, Bianco JJ, Cunha GR, Wang Y, Risbridger GP. Prostatic hormonal carcinogenesis is mediated by in situ estrogen production and estrogen receptor $\alpha$ signalling. FASEB J. 2008; 22:1512-1520. [PubMed: 18055862]

26. Cussenot O, Azzouzi AR, Nicolaiew N, et al. Combination of polymorphisms from genes related to estrogen metabolism and risk of prostate cancers: the hidden face of estrogens. J Clin Oncol. 2007; 25:3596-3602. [PubMed: 17704407]

27. John K, Ragavan N, Pratt MM, et al. Quantification of phase I/II metabolizing enzyme gene expression and polycyclic aromatic hydrocarbon-DNA adduct levels in human prostate. Prostate. 2009; 69(5):505-519. [PubMed: 19143007]

28. Ragavan N, Hewitt R, Cooper LJ, et al. CYPB1 expression in prostate is higher in the peripheral than in the transition zone. Cancer Lett. 2004; 215(1):69-78. [PubMed: 15374634]

29. Rohrmann S, Nelson WG, Rifai N. Serum estrogen, but not testosterone, levels differ between black and white men in a nationally representative sample of Americans. J Clin Endocrinol Metab. 2007; 92(7):2519-2525. [PubMed: 17456570]

30. Henderson BE, Bernstein L, Ross RK, Depue RH, Judd HL. The early in utero oestrogen and testosterone environment of blacks and whites: potential effects on male offspring. Br J Cancer. 1988; 57:216-218. [PubMed: 3358915]

31. Powell IJ, Meyskens FL Jr. African American men and hereditary/familial prostate cancer: intermediate-risk populations for chemoprevention trials. Urology. 2001; 57:178-181. [PubMed: 11295621]

32. Ho SM, Roy D. Sex hormone-induced nuclear DNA damage and lipid peroxidation in the dorsolateral prostates of Noble rats. Cancer Lett. 1994; 84:155-162. [PubMed: 8076372]

33. Leav I, Ho SM, Ofner P, Merk FB, Kwan PW, Damassa D. Biochemical alterations in sex hormone-induced hyperplasia and dysplasia of the dorsolateral prostates of Noble rats. J Natl Cancer Inst. 1988; 80:1045-1053. [PubMed: 2457709]

34. Bosland MC, Ford H, Horton L. Induction of a high incidence of ductal prostate adenocarcinoma in NBL and Sprague Dawley rats treated with estrdaiol-17 $\beta$ or diethylstilbestrol in combination with testosterone. Carcinogenesis. 1995; 16:1311-1317. [PubMed: 7788848]

35. Bosland MC. The role of estrogens in prostate carcinogenesis: a rationale for chemoprevention. Rev Urol. 2005; 7(3):S4-S10. Discusses the role of estrogens in prostate cancer carcinogenesis with particular emphasis on the testosterone plus estrogen model of inducing prostate cancer in Noble rats. [PubMed: 16985878]

36. Arai Y, Chen CY, Nishizuka Y. Cancer development in male reproductive tract in rats given diethylstilbestrol at neonatal age. Gann. 1978; 69(6):861-862. [PubMed: 750279]

37. McLachlan JA, Newbold RR, Li S, Negishi M. Are estrogens carcinogenic during development of the testes? APMIS. 1998; 106:240-244. [PubMed: 9524585]

38. Prins GS, Huang L, Birch L, Pu Y. The role of estrogens in normal and abnormal development of the prostate gland. Ann NY Acad Sci. 2006; 1089:1-13. [PubMed: 17261752]

39. Prins GS, Birch L, Tang WY, Ho SM. Developmental estrogen exposures predispose to prostate carcinogenesis with aging. Rep Toxicol. 2007; 23(3):374-382.

40. Kasper S. Exploring the origins of the normal prostate and prostate cancer stem cell. Stem Cell Rev. 2008; 4:193-201. [PubMed: 18563640]

41. Miki J, Rhim J. Prostate cell cultures as in vitro models for the study of normal stem cells and cancer stem cells. Prostate Cancer Prostatic Dis. 2008; 11:32-39. [PubMed: 17984999]

42. Gu G, Yuan J, Wills M, Kasper S. Prostate cancer cells with stem cell characteristics reconstitute the original tumor in vivo. Cancer Res. 2007; 67:4708-4715.

43. Leong KG, Wang BE, Johnson L, Gao WQ. Generation of a prostate from a single cell. Nature. 2008; 456:804-808. [PubMed: 18946470]

44. Vander Griend DJ, Karthaus WL, Dalrymple S, Meeker A, DeMarzo AM, Isaacs JT. The role of CD133 in normal human prostate stem cells and malignant cancer-initiating cells. Cancer Res. 2008; 68:9703-9711. [PubMed: 19047148] 
45. Isaacs JT, Coffey DS. Etiology and disease process of benign prostatic hyperplasia. Prostate Suppl. 1989; 2:33-50. [PubMed: 2482772]

46. Lang SH, Stark M, Collins A, et al. Experimental prostate morphogenesis in response to stroma and three dimensional matrigel culture. Cell Growth Differ. 2001; 12:631-640. [PubMed: 11751458]

47. Goldstein AS, Lawson DA, Cheng D, Sun W, Garraway IP, Witte ON. Trop2 identifies a subpopulation of murine and human prostate basal cells with stem cell characteristics. Proc Natl Acad Sci USA. 2008; 105:20882-20887. [PubMed: 19088204]

48. Garraway IP, Sun W, Tran CP, et al. Human prostate sphere-forming cells represent a subset of basall epithelial cells capable of glandular regeneration in vivo. Prostate. 2010; 40:491-501. [PubMed: 19938015]

49•. Hu WY, Shi GB, Hu DP, et al. Estrogen-initiated transformation of prostate epithelium derived from normal human prostate stem-progenitor cells. Endocrinology. 2011 (Epub ahead of print). Represents the first direct evidence of hormone-initiated cancer in normal human prostate epithelial cells. 10.1210/en.2010-1377

50. Taylor RA, Cowin PA, Cunha GR, et al. Formation of human prostate tissue from embryonic stem cells. Nat Methods. 2006; 3:179-181. [PubMed: 16489334]

51. Titus-Emstoff L, Hatch EE, Hoover RN, et al. Long term risk in women given diethylstilbestrol (DES) during pregnancy. Br J Cancer. 2001; 84:126-133. [PubMed: 11139327]

52. Colton T, Greenberg ER, Noller K, et al. Breast cancer in mothers prescribed diethylstilbestrol in pregnancy. Further follow-up JAMA. 1993; 269:2096-2100.

53. Herbst AL, Ulfelder H, Poskanzer DC. Adenocarcinoma of the vagina. Association of maternial stilbestrol therapy with tumor appearance in women. N Engl J Med. 1971; 284:878-881. [PubMed: 5549830]

54. Herbst AL, Poskanzer DC, Robboy SJ, Friedlander L, Scully RE. Prenatal exposure to stibestrol. A prospective comparison of exposed female offspring with unexposed controls. N Engl J Med. 1976; 292:334-339. [PubMed: 1117962]

55. Palmer JR, Wise LA, Hatch EE, et al. Prenatal diethylstilbestrol exposure and risk of breast cancer. Cancer Epidemiol Biomark Prev. 2006; 15:1509-1514.

56. Driscoll SG, Taylor SH. Effects of the prenatal maternal estrogen on the male urogenital system. Obstet Gynecol. 1980; 56:537-542. [PubMed: 7432722]

57. Ekbom A, Wuu J, Adami HO, et al. Duration of gestation and prostate cancer risk in offspring. Cancer Epidemiol Biomarkers Prev. 2000; 9:221-223. [PubMed: 10698486]

58. Prins GS, Birch L, Habermann H, et al. Influence of neonatal estrogens on rat prostate development. Reprod Fertil Dev. 2001; 13:241-252. [PubMed: 11800163]

59. Huang L, Pu Y, Alam S, Birch L, Prins GS. Estrogenic regulation of signaling pathways and homeobox genes during rat prostate development. J Androl. 2004; 25:330-337. [PubMed: 15064308]

60. Prins, GS. Developmental estrogenization of the prostate gland. In: Naz, RK., editor. Prostate: Basic and Clinical Aspects. CRC Press; FL, USA: 1997. p. 247-265.

61. Bosland MC, Ford H, Horton L. Induction at high incidence of ductal prostate adenocarcinomas in NBL/Cr and Sprague-Dawley Hsd:SD rats treated with a combination of testosterone and estradiol-17B or dietlhylstilbestrol. Carcinogenesis. 1995; 16:1311-1317. [PubMed: 7788848]

62. Ho SM, Wang WY, Belmonte J, Prins GS. Developmental exposure estradiol and bisphenol A (BPA) increases susceptibility to prostate carcinogenesis and epigenetically regulates phosphodisesterase type 4 variant (PDE4D4) in the rat prostate. Cancer Res. 2006; 66:56245632. Provides evidence that exposure of rats to estrogens during prostate development, ranging from environmental bisphenol A exposure to pharmacologic doses of estradiol, results in increased susceptibility to carcinogenesis later in life and identified the involvement of epigenetic alterations that may underlie this developmental reprogramming. [PubMed: 16740699]

63. Prins GS, Ye SH, Birch L, Ho SM, Kannan K. Serum bisphenol A pharmacokinetics and prostatic responses following oral and subcutaneous exposures in neonatal sprague-dawley rats. Reprod Toxicol. 2011; 31(1):1-9. [PubMed: 20887781] 
64. Prins GS, Ho SM. Early life estrogens and prostate cancer in an animal model. J Dev Orig Health Dis. 2010; 1:365-370.

65. Esteller M. Aberrant DNA methylation as a cancer-inducing mechanism. Annu Rev Pharmacol Toxicol. 2005; 45:629-656. [PubMed: 15822191]

66. Feinberg AP, Ohlsson R, Henikoff S. The epigenetic progenitor origin of human cancer. Nat Rev. 2006; 7:21-33.

67. Yegnasubramanian S, Kowalski J, Gonzalgo ML, et al. Hypermethylation of CpG islands in primary and metastatic human prostate cancer. Cancer Res. 2004; 64:1975-1986. [PubMed: 15026333]

68. Enokida H, Shiina H, Urakami S, et al. Multigene methylation analysis for detection and staging of prostate cancer. Clin Cancer Res. 2005; 11:6582-6588. [PubMed: 16166436]

69. Vardi A, Bosviel R, Rabiau N, et al. Soy phytoestrogens modify DNA methylation of GSTP1, RASSF1A, EPH2 and BRCA1 promoter in prostate cancer cells. In Vivo. 2010; 24(4):393-400. [PubMed: 20668305]

70. Majid S, Dar AA, Shahryari V, et al. Genistein reverses hypermethylation and induces active histone modifications in tumor-suppressor gene B-cell translocation gene 3 in prostate cancer. Cancer. 2010; 116(1):66-76. [PubMed: 19885928]

71. Kikuno N, Shiina H, Urakami S, et al. Genistein mediated histone acetylation and demethylation activates tumor-suppressor genes in prostate cancer cells. Int J Cancer. 2008; 123(3):552-560. [PubMed: 18431742]

72. Li S, Washburn KA, Moore R, et al. Developmental exposure to diethylstilbestrol elicits demethylation of estrogen-responsive lactorfferrin gene in mouse uterus. Cancer Res. 1997; 57:4356-4359. [PubMed: 9331098]

73. Alworth LC, Howdeshell KL, Ruhlen RL, et al. Uterine responsiveness to estradiol and DNA methylation are altered by fetal exposure to diethylstilbestrol and methoxychlor in CD-1 mice: effects of low versus high doses. Toxicol Appl Pharmacol. 2002; 183:10-22. [PubMed: 12217638]

74. Anway MD, Cupp AS, Uzumcu M, Skinner MK. Epigenetic transgenerational actions of endocrine disuptors and male fertility. Science. 2005; 308:1466-1469. [PubMed: 15933200]

75. Lang R, Redmann U. Non-mutagenicity of some sex hormones in the salmonella/microsome mutagenicity test. Mutat Res. 1979; 67:361- 365. [PubMed: 384238]

76. Liehr JG, Fang WF, Sirbasku DA, Ari-Ulubelen A. Carcinogenicity of catechol estrogens in Syrian hamsters. J Steroid Biochem. 1986; 24:353-356. [PubMed: 3009986]

77. Lang R, Reiman R. Studies for a genotoxic potential of some endogenous and exogenous sex steroids. I Communication: examination for the induction of gene mutations using the Ames Salmonella/microsome test and the HGPRT test in V79 cells. Environ Mol Mutagen. 1993; 21:272-304. [PubMed: 8462531]

78. Drevon C, Piccoli C, Montesano R. Mutagenicity assays of estrogenic hormones in mammalian cells. Mutat Res. 1981; 89:83-90. [PubMed: 7242549]

79. Rajah TT, Pento JT. The mutagenic potential of antiestrogens at the HPRT locus in V79 cells. Res Commun Mol Pathol Pharmacol. 1995; 89:85-92. [PubMed: 7582865]

80. Tsutsui T, Suzuki N, Fukuda S, et al. 17 $\beta$-estradiol-induced cell transformation and aneuploidy of Syrian hamster embryo cells in culture. Carcinogenesis. 1987; 8:1715-1719. [PubMed: 3664964]

81. Tsutsui T, Barrett JC. Neoplastic transformation of cultured mammalian cells by estrogens and estrogen-like chemicals. Environ Health Perspect. 1997; 105:619-324. [PubMed: 9168005]

82. Tsutsui T, Taguchi S, Tanaka Y, Barrett JC. 17ß-estradiol, diethylstilbestrol, tamoxifen, toremifene and ICI 164,384 induce morphological transformation and aneuploidy in cultured Syrian hamster embryo cells. Int J Cancer. 1997; 70:188-193. [PubMed: 9009159]

83. Banerjee, SH.; Banerjee, S.; Li, SA.; Li, JJ. Cytogenetic changes in renal neoplasms and during estrogen-induced carcinogenesis. In: Li, JJ.; Nandi, S.; Li, SA., editors. Hormonal Carcinogenesis. Springer-Verlag; NY, USA: 1992. p. 247-251.

84. Banerjee SK, Banerjee S, Li SA, Li JJ. Induction of chromosome aberrations in Syrian hamster renal cortical cells by various estrogens. Mutat Res. 1994; 311:191-197. [PubMed: 7526183] 
85. Tsutsui T, Suzuki N, Maizumi H, Barrett JC. Aneuploidy induction in human fibroblasts: comparison with results in Syrian hamster fibroblasts. Mutat Res. 1990; 240:241-249. [PubMed: 2330010]

86. Hunt PA, Koehler KE, Susiarjo M, et al. Bisphenol A exposure causes meiotic aneuploidy in the female mouse. Curr Biol. 2003; 13:546-553. [PubMed: 12676084]

87. Sisiarjo M, Hassold TJ, Freeman E, Hunt PA. Bisphenol A exposure in utero disrupts early oogenesis in the mouse. PloS Genet. 2007; 3(1):63-70.

88. Jones LA, Hajek RA. Effects of estrogenic chemicals on development. Environ Health Perspect. 1995; 103:63-67. [PubMed: 8593877]

89. Hajek RA, Pathak S, Boddie AK, Jones LA. Aneuploidy of mouse cervicovaginal epithelium induced by perinatal estrogen treatment. Proc Am Assoc Cancer Res. 1989; 30:299.

90. Li JJ, Hou X, Banerjee SK, et al. Overexpression and amplification of c-myc in the Syrian hamster kidney during estrogen carcinogenesis: a probable critical role in neoplastic transformation. Cancer Res. 1999; 59:2340-2346. [PubMed: 10344741]

91. Hodgson AV, Ayala-Torres S, Thompson EB, Liehr JG. Estrogen-induced microsatellite DNA alterations are associated with Syrian hamster kidney tumorigenesis. Carcinogenesis. 1998; 19:2169-2172. [PubMed: 9886574]

92. Yared E, McMillan TJ, Martin FL. Genotoxic effects of oestrogens in breast cells detected by the micronucleus assay and the Comet assay. Mutagenesis. 2002; 17(4):345-352. [PubMed: 12110632]

93. Cavalieri EL, Frenkel K, Liehr JG, Rogan EG, Roy D. Estrogens as endogenous genotoxic agents DNA adducts and mutations. J Natl Cancer Inst. 2000; 27:75-93.

94. Martin FL, Patel I, Sozeri O, et al. Constitutive expression of bioactivating enzymes in normal human prostate suggests a capability to activate pro-carcinogens to DNA-damaging metabolites. Prostate. 2010; 70:1586-1599. [PubMed: 20687231]

95. Tang YM, Green BL, Chen GF, et al. Human CYP1B1 Leu432 Val gene polymorphism: ethnic distribution in African-Americans, Caucasians and Chinese; oestradiol hydroxylase activity; and distribution in prostate cancer cases and controls. Pharmacogenetics. 2000; 10:761-766. [PubMed: 11221602]

96. Bartke A, Doherty P, Steger R, et al. Effects of estrogen-induced hyperprolactinemia on endocrine and sexual functions in adult male rats. Neuroendocrinology. 1984; 39:126-135. [PubMed: 6382042]

97. Harvey PW, Everett DJ, Springall CJ. Hyperprolactinaemia as an adverse effect in regulatory and clinical toxicology: role in breast and prostate cancer. Hum Exp Toxicol. 2006; 25(7):395-404. [PubMed: 16898168]

98. Jacobson EM, Hugo ER, Tuttle TR, Papoian R, Ben-Jonathan N. Unexploited therapies in breast and prostate cancer: blockade of the prolactin receptor. Trends Endocrinol Metab. 2010; 21(11): 691-698. [PubMed: 20846877]

99. Fernandez I, Touraine P, Goffin V. Prolactin and human tumourogenesis. J Neuroendocrinol. 2010; 22(7):771-777. [PubMed: 20456598]

100. Li J, Ahonen TJ, Alanen K, et al. Activation of signal transducer and activator of transcription 5 in human prostate cancer is associated with high histological grade. Cancer Res. 2004; 64(14): 4774-4782. [PubMed: 15256446]

101. Tan SH, Dagvadorj A, Shen F, et al. Transcription factor Stat5 synergizes with androgen receptor in prostate cancer cells. Cancer Res. 2008; 68(1):236-248. [PubMed: 18172316]

102. Ahonen TJ, Härkönen PL, Laine J, Rui H, Martikainen PM, Nevalainen MT. Prolactin is a survival factor for androgen-deprived rat dorsal and lateral prostate epithelium in organ culture. Endocrinology. 1999; 140:5412-5421. [PubMed: 10537173]

103. Prins GS. Prolactin influence on cytosol and nuclear androgen receptors in the ventral, dorsal, and lateral lobes of the rat prostate. Endocrinology. 1987; 120(4):1457-1464. [PubMed: 3493896]

104. Van Coppenolle F, Slomianny C, Carpentier F. Effects of hyperprolactinemia on rat prostate growth: evidence of androgeno-dependence. Am J Physiol Endocrinol Metab. 2001; 280(1):E120-E129. [PubMed: 11120666] 
105. Gilleran JP, Putz O, DeJong M, et al. The role of prolactin in the prostatic inflammatory response to neonatal estrogen. Endocrinology. 2003; 144(5):2046-2054. [PubMed: 12697713]

106•. Tam NN, Szeto CY, Freudenberg JM, Fullenkamp AN, Medvedovic M, Ho SM. Research resource: estrogen-driven prolactin-mediated gene-expression networks in hormone-induced prostatic intraepithelial neoplasia. Mol Endocrinol. 2010; 24(11):2207-2217. The authors used global gene-expression ana lysis to identify those genes whose expression was significantly altered in the prostates of rats treated with testosterone plus estrogen and found that prolactin blockade was required to block over $80 \%$ of these changes. These findings implicate estrogeninduced hyperprolactinemia as an important mediator of estrogen action in prostate carcinogenesis. [PubMed: 20861223]

107. Fenner A. Prostate cancer: antagonizing the prolactin receptor prevents tumorigenesis in a transgenic mouse model of prostate cancer. Nat Rev Urol. 2010; 7(11):591. [PubMed: 21113991]

108. Prins GS, Birch L. Neonatal estrogen exposure up-regulates estrogen receptor expression in the developing and adult rat prostate lobes. Endocrinology. 1997; 138(5):1801-1809. [PubMed: 9112371]

109. Bianco JJ, McPherson SJ, Wang H, Prins GS, Risbridger GP. Transient neonatal estrogen exposure to estrogen-deficient mice (aromatase knockout) reduces prostate weight and induces inflammation in late life. Am J Pathol. 2006; 168:1869-1878. [PubMed: 16723702]

110. Ellem SJ, Wang H, Poutanen M, Rispbridger G. Increased endogenous estrogen synthesis leads to the sequential induction of prostatic inflammation (prostatitis) and prostatic pre-malignancy. Am J Pathol. 2009; 175:1187-1199. [PubMed: 19700748]

111. Harris MT, Feldberg RS, Lau KM, Lazarus NH, Cochrane DE. Expression of proinflammatory genes during estrogen-induced inflammation of the rat prostate. Prostate. 2000; 44:19-25. [PubMed: 10861753]

112. Balkwill F, Mantovani A. Inflammation and cancer: back to Virchow? Lancet. 2001; 357:539_ 545. [PubMed: 11229684]

113. Coussens LM, Werb Z. Inflammation and cancer. Nature. 2002; 420:860-867. [PubMed: 12490959]

114. Kuper H, Adami HO, Trichopoulos D. Infections as a major preventable cause of human cancer. J Intern Med. 2000; 248:171-183. [PubMed: 10971784]

115. De Marzo AM, Marchi VL, Epstein JI, Nelson WG. Proliferative inflammatory atrophy of the prostate: implications for prostatic carcinogenesis. Am J Pathol. 1999; 155:1985-1992. [PubMed: 10595928]

116. Palapattu GS, Sutcliffe S, Bastian PJ, et al. Prostate carcinogenesis and inflammation: emerging insights. Carcinogenesis. 2005; 26:1170-1181. [PubMed: 15498784]

117. Dennis LK, Dawson DV. Meta-analysis of measures of sexual activity and prostate cancer. Epidemiology. 2002; 13:72-79. [PubMed: 11805589]

118. Ruska KM, Sauvageot J, Epstein JI. Histology and cellular kinetics of prostatic atrophy. Am J Surg Pathol. 1998; 22:1073-1077. [PubMed: 9737239]

119. Woenckhaus J, Fenic I. Proliferative inflammatory atrophy: a background lesion of prostate cancer? Andrologia. 2008; 40(2):134-137. [PubMed: 18336466]

120. Frenkel K, Wei L, Wei H. 7, 12-Dimethylbenz[a]anthracene induces oxidative DNA modification in vivo. Free Radic Biol Med. 1995; 19:373-380. [PubMed: 7557552]

121. Elmets CA, Athar M, Tubesing KA, et al. Susceptibility to the biological effects of polyaromatic hydrocarbons is influenced by genes of the major histocompatibility complex. Proc Natl Acad Sci USA. 1998; 95:14915-14919. [PubMed: 9843990]

122. Casale GP, Cheng Z, Liu J, et al. Profiles of cytokine mRNAs in the skin and lymph nodes of SENCAR mice treated epicutaneously with dibenzo[a, 1]pyrene or dimethylbenz[a]anthracene reveal a direct correlation between carcinogen-induced contact hypersensitivity and epidermal hyperplasia. Mol Carcinog. 2000; 27:125-140. [PubMed: 10657905]

123. Lewis CE, Leek R, Harris A, et al. Cytokine regulation of angiogenesis in breast cancer: the role of tumor-associated macrophages. J Leukoc Biol. 1995; 57:747-751. [PubMed: 7539028] 
124. Chen Z, Malhotra PS, Thomas GR, et al. Expression of proinflammatory and proangiogenic cytokines in patients with head and neck cancer. Clin Cancer Res. 1999; 5:1369-1379. [PubMed: 10389921]

125. Inoue K, Slaton JW, Eve BY, et al. Interleukin 8 expression regulates tumorigenicity and metastases in androgen-independent prostate cancer. Clin Cancer Res. 2000; 6:2104-2119. [PubMed: 10815938]

126. Mahmud SM, Franco EL, Aprikian AG. Use of nonsteroidal anti-inflammatory drugs and prostate cancer risk: a meta-analysis. Int J Cancer. 2010; 127(7):1680-1691. [PubMed: 20091856]

127. Dhillon PK, Kenfield SA, Stampfer MJ, Giovannucci EL. Long-term aspirin use and the risk of total, high-grade, regionally advanced and lethal prostate cancer in a prospective cohort of health professionals, 1988-2006. Int J Cancer. 2010; 128(10):2444-2452. [PubMed: 21128233]

128. Brasky TM, Velicer CM, Kristal AR, Peters U, Potter JD, White E. Non-steroidal antiinflammatory drugs and prostate cancer risk in the VITamins And Lifestyle (VITAL) cohort. Cancer Epidemiol Biomarkers Prev. 2010; 19(7):1696-1708. [PubMed: 20615886]

129. Mueller SO, Korach SK. Estrogen receptors and endocrine diseases. Lessons from estrogen receptor knockout mice. Curr Opin Pharmacol. 2001; 1:613-619. [PubMed: 11757817]

130. Bonkhoff $\mathrm{H}$, Berges R. The evolving role of oestrogens and their receptors in the development and progression of prostate cancer. Eur Urol. 2009; 55:533-542. [PubMed: 19013008]

131. Chang WY, Prins GS. Estrogen receptor- $\beta$ : implications for the prostate gland. Prostate. 1999; 40:115-124. [PubMed: 10386472]

132. Ho SM. Estrogens and anti-estrogens: key mediators of prostate carcinogenesis and new therapeutic candidates. J Cell Biochem. 2004; 91:491-503. [PubMed: 14755680]

133. Risbridger GP, Ellem SJ, McPherson SJ. Estrogen action on the prostate gland: a critical mix of endocrine and paracrine signalling. J Mol Endocrinol. 2007; 39:183-188. [PubMed: 17766643]

134. Singh PB, Matanhelia SS, Martin FL. A potential paradox in prostate adenocarcinoma progression: oestrogen as the initiating driver. Eur J Cancer. 2008; 44:928-936. [PubMed: 18381236]

135. Bonkhoff H, Fixemer T, Hunsicker I, Remberger K. Estrogen receptor expression in prostate cancer and premalignant prostatic lesions. Am J Pathol. 1999; 155:641-647. [PubMed: 10433957]

136. Edwards DP. Regulation of signal transduction pathways by estrogen and progesterone. Annu Rev Physiol. 2005; 67:335-376. [PubMed: 15709962]

137. Levin ER. Plasma membrane estrogen receptors. Trends Endocrinol Metab. 2009; 20(10):489494.

138. O'Dowd BF, Nguyen T, Marchese A, et al. Discovery of three novel G-protein-coupled receptor genes. Genomics. 1998; 47(2):310-313. [PubMed: 9479505]

139. Bonkhoff H, Remberger K. Differentiation pathways and histogenetic aspects of normal and abnormal prostatic growth: a stem cell model. Prostate. 1996; 28:98-106. [PubMed: 8604398]

140. Prins GS, Birch L, Couse JF, Choi I, Katzenellenbogen B, Korach KS. Estrogen imprinting of the developing prostate gland is mediated through stromal estrogen receptor $\alpha$ : studies with $\alpha \mathrm{ERKO}$ and $\beta E R K O$ mice. Cancer Res. 2001; 61:6089-6097. [PubMed: 11507058]

141. Bonkhoff H, Fixemer T, Hunsicker I, Remberger K. Progesterone receptor expression in human prostate cancer: correlation with tumor progression. Prostate. 2001; 48(4):285-291. [PubMed: 11536308]

142. Bonkhoff H, Stein U, Welter C, Remberger K. Differential expression of the PS2 protein in the human prostate and prostate cancer: association with premalignant changes and neuroendocrine differentiation. Hum Pathol. 1995; 26(8):824-828. [PubMed: 7635445]

143. Price D, Stein B, Sieber P, et al. Toremifene for the prevention of prostate cancer in men with high grade prostatic intraepithelial neoplasia: results of a double-blind, placebo controlled, Phase IIB clinical trial. J Urol. 2006; 176:965-970. [PubMed: 16890670]

144. Kuiper GG, Enmark E, Pelto-Huikko M, Nilsson S, Gustafsson JA. Cloning of anovel receptor expressed in rat prostate and ovary. Proc Natl Acad Sci USA. 1996; 93:5925-5930. [PubMed: 8650195] 
145. Fixemer T, Remberger K, Bonkhoff H. Differential expression of the estrogen receptor $\beta$ (ER $\beta$ ) in human prostate tissue, premalignant changes, and in primary, metastatic, and recurrent prostatic adenocarcinoma. Prostate. 2003; 54:79-87. [PubMed: 12497580]

146. Adams JY, Leav I, Lau KM, Ho SM, Pflueger SM. Expression of estrogen receptor $\beta$ in the fetal, neonatal, and prepubertal human prostate. Prostate. 2002; 52(1):69-81. [PubMed: 11992621]

147. Hedelin M, Bälter KA, Chang ET, et al. Dietary intake of phytoestrogens, estrogen receptor- $\beta$ polymorphisms and the risk of prostate cancer. Prostate. 2006; 66:1512-1520. [PubMed: 16921512]

148. Leav I, Lau KM, Adams JY, et al. Comparative studies of the estrogen receptors $\beta$ and $\alpha$ and the androgen receptor in normal human prostate glands, dysplasia, and in primary and metastatic carcinoma. Am J Pathol. 2001; 159(1):79-92. [PubMed: 11438457]

149. Zhu X, Leav I, Leung YK, et al. Dynamic regulation of estrogen receptor- $\beta$ expression by DNA methylation during prostate cancer development and metastasis. Am J Pathol. 2004; 164(6): 2003-2012. [PubMed: 15161636]

150. Mak P, Leav I, Pursell B. ERB impedes prostate cancer EMT by destabilizing HIF-1 $\alpha$ and inhibiting VEGF-mediated snail nuclear localization: implications for Gleason grading. Cancer Cell. 2010; 17:319-332. [PubMed: 20385358]

151 . McPherson SJ, Hussain S, Balanathan P, et al. Estrogen receptor- $\beta$ activated apoptosis in benign hyperplasia and cancer of the prostate is androgen independent and TNF $\alpha$ mediated. Proc Natl Acad Sci USA. 2010; 107(7):3123-3128. Demonstrates that activation of ER $\beta$ by a receptorspecific ligand drives prostate epithelial and stromal cell apoptosis through a caspase- 8 pathway and identifies a critical role for TNF- $\alpha$ in this process. [PubMed: 20133657]

152. Maggiolini M, Picard D. The unfolding stories of GPR30, a new membrane bound estrogen receptor. J Endocrinol. 2009; 204:105-114. [PubMed: 19767412]

153. Maggiolini M, Vivacqua A, Fasanella G, et al. The G protein-coupled receptor GPR30 mediates c-fos up-regulation by $17 \beta$-estradiol and phytoestrogens in breast cancer cells. J Biol Chem. 2004; 279:27008-27016. [PubMed: 15090535]

154. Albanito L, Sisci D, Aquila S, et al. EGF induces GPR30 expression in estrogen receptor-negative breast cancer cells. Endocrinology. 2008; 149:3799-3808. [PubMed: 18467441]

155. Vivacqua A, Bonofiglio D, Recchia AG, et al. The G protein-coupled receptor GPR30 mediates the proliferative effects induced by $17 \beta$-estradiol and hydroxytamoxifen in endometrial cancer cells. Mol Endocrinol. 2006; 20:631-646. [PubMed: 16239258]

156. Vivacqua A, Lappano R, De Marco P, et al. G protein-coupled receptor 30 expression is upregulated by EGF and TGF $\alpha$ in estrogen receptor $\alpha$-positive cancer cells. Mol Endocrinol. 2009; 23:1815-1826. [PubMed: 19749156]

157. Revankar CM, Cimino DF, Sklar LA, Arterburn JB, Prossnitz ER. A transmembrane intracellular estrogen receptor mediates rapid cell signaling. Science. 2005; 307:1625-1630. [PubMed: 15705806]

158. Albanito L, Madeo A, Lappano R, et al. G protein-coupled receptor 30 (GPR30) mediates gene expression changes and growth response to $17 \beta$-estradiol and selective GPR30 ligand G-1 in ovarian cancer cells. Cancer Res. 2007; 67:1859-1866. [PubMed: 17308128]

159. Vivacqua A, Bonofiglio D, Albanito L, et al. $17 \beta$-estradiol, genistein and 4-hydroxytamoxifen induce the proliferation of thyroid cancer cells through the $\mathrm{G}$ protein-coupled receptor GPR30. Mol Pharmacol. 2006; 70:1414-1423. [PubMed: 16835357]

160. Ariazi EA, Brailoiu E, Yerrum S, et al. The G protein-coupled receptor GPR30 inhibits proliferation of estrogen receptor-positive breast cancer cells. Cancer Res. 2010; 70:1184-1194. [PubMed: 20086172]

161. Prossnitz ER, Sklar LA, Oprea TI, Arterburn JB. GPR30: a novel therapeutic target in estrogenrelated disease. Trends Pharmacol Sci. 2008; 29:116-123. [PubMed: 18262661]

162. Dong S, Terasaka S, Kiyama R. Bisphenol A induces a rapid activation of Erk1/2 through GPR30 in human breast cancer cells. Environ Pollut. 2010; 159(1):212-218. [PubMed: 20875696]

163. Filardo EJ, Graeber CT, Quinn JA, et al. Distribution of GPR30, a seven membrane-spanning estrogen receptor, in primary breast cancer and its association with clinico-pathologic determinants of tumor progression. Clin Cancer Res. 2006; 12:6359-6366. [PubMed: 17085646] 
164. Arias-Pulido H, Royce M, Gong Y, et al. GPR30 and estrogen receptor expression: new insights into hormone dependence of inflammatory breast cancer. Breast Cancer Res Treat. 2010; 123(1): 51-58. [PubMed: 19902352]

165. Madeo A, Maggiolini M. Nuclear alternate estrogen receptor GPR30 mediates 17ๆ-estradiolinduced gene expression and migration in breast cancer-associated fibroblasts. Cancer Res. 2010; 70(14):6036-6046. [PubMed: 20551055]

166. Karnoub AE, Dash AB, Vo AP, et al. Bone marrow-derived mesenchymal stem cells promote breast cancer metastasis. Nature. 2007; 449:557-563. [PubMed: 17914389]

167. Bhowmick NA, Neilson EG, Moses HL. Stromal fibroblasts in cancer initiation and progression. Nature. 2004; 432:332-337. [PubMed: 15549095]

168. Kalluri R, Zeisberg M. Fibroblasts in cancer. Nat Rev Cancer. 2006:392-401. [PubMed: 16572188]

169. Chan QKY, Lam HM, Ng CF, et al. Activation of GPR30 inhibits growth of prostate cancer cells via sustained activation of Erk1/2, c-jun/c-fos-dependendent upregulation of p21, and induction of G2 cell-cycle arrest. Cell Death Differ. 2011; 17(9):1511-1523. [PubMed: 20203690]

170. Zhou HB, Carlson KE, Stossi F, et al. Analogs of methyl-piperidinopyrazole (MPP): antiestrogens with estrogen receptor $\alpha$ selective activity. Bioorg Med Chem Lett. 2009; 19(1): 108-110. [PubMed: 19014882]

171. Meyers MJ, Sun J, Carlson KE, et al. Estrogen receptor- $\alpha$ potency-selective ligands: structureactivity relationship studies of diarylpropionitriles and their acetylene and polar analogs. J Med Chem. 2001; 44(24):4230-4251. [PubMed: 11708925]

172. Neubauer BL, Best KL, Counts DF, et al. Raloxifene (LY156758) producesantimetastatic responsesandextends survival in the PAIII rat prostatic adenocarcinoma model. Prostate. 1995; 27:220-229. [PubMed: 7479389]

173. Kim IY, Seong DH, Kim BC, et al. Raloxifene, a selective estrogen receptor modulator, induces apoptosis in androgen- responsive human prostate cancer cell line LNCaP through an androgenindependent pathway. Cancer Res. 2002; 62:3649-3653. [PubMed: 12097269]

174. Kim IY, Kim BC, Seong DH, et al. Raloxifene, a mixed estrogen agonist/antagonist, induces apoptosis in androgen-independent human prostate cancer cell lines. Cancer Res. 2002; 62:53655369. [PubMed: 12235008]

175. Neubauer BL, McNulty AM, Chedid M, et al. The selective estrogen receptor modulator trioxifene (LY133314) inhibits metastasis and extends survival in the PAIII rat prostatic carcinoma model. Cancer Res. 2003; 63:6056-6062. [PubMed: 14522935]

176. Bhattacharyya RS, Krishnan AV, Swami S, Feldman D. Fulvestrant (ICI 182,780) down-regulates androgen receptor expression and diminishes androgenic responses in LNCaP human prostate cancer cells. Mol Cancer Ther. 2006; 5:1539-1549. [PubMed: 16818513]

177. Chadha MK, Ashraf U, Lawrence D, et al. Phase II study of fulvestrant (Faslodex) in castration resistant prostate cancer. Prostate. 2008; 68:1461-1466. [PubMed: 18618738]

178. Raghow S, Hooshdaran MZ, Katiyar S, Steiner MS. Toremifene prevents prostate cancer in the transgenic adenocarcinoma of mouse prostate model. Cancer Res. 2002; 62:1370-1376. [PubMed: 11888907]

179•. Setlur SR, Mertz KD, Hoshida Y, et al. Estrogen-dependent signaling in a molecularly distinct subclass of aggressive prostate cancer. J Natl Cancer Inst. 2008; 100:815-825. Demonstrates that $\mathrm{ER} \alpha$ agonists increase the expression of TMPRSS2 ERG fusion protein that is expressed in up to $70 \%$ of local prostate cancers. By contrast, treatment with an ER $\beta$ agonist resulted in a decrease in expression, with corresponding changes in cancer cell viability. [PubMed: 18505969]

180. Bergan RC, Reid E, Myers CE. A Phase II study of high-dose tamoxifen in patients with hormone-refractory prostate cancer. Clin Cancer Res. 1999; 5(9):2366-2373. [PubMed: 10499606]

181. Smith MR, Malkowicz SB, Chu F, et al. Toremifene increases bone mineral density in men receiving androgen deprivation therapy for prostate cancer: interim analysis of a multicenter Phase 3 clinical study. J Urol. 2008; 179:152-155. [PubMed: 18001802] 
182. Smith MR, Malkowicz SB, Chu F, et al. Toremifene improves lipid profiles in men receiving androgendeprivation therapy for prostate cancer: interim analysis of a multicenter Phase III study. J Clin Oncol. 2008; 26:1824-1829. [PubMed: 18398147]

183. Taylor SE, Martin-Hirsch PL, Martin FL. Oestrogen receptor splice variants in the pathogenesis of disease. Cancer Lett. 2010; 288(2):133-148. [PubMed: 19608332]

184. Taylor SE, Patel II, Singh PB, et al. Elevated oestrogen receptor splice variant ER $\alpha \Delta 5$ expression in tumour-adjacent hormone responsive tissue. Int J Environ Res Public Health. 2010; 7(11): 3871-3889. [PubMed: 21139866]

185. Parkin DM, Bray F, Ferlay J, Pisani P. Global Cancer Statistics, 2002. CA Cancer J Clin. 2005; 55:74-108. [PubMed: 15761078]

186. Hwang YW, Kim SY, Jee SH, Kim YN, Nam CM. Soy food consumption and risk of prostate cancer: a meta-analysis of observational studies. Nutr Cancer. 2009; 61(5):598-606. [PubMed: 19838933]

187. Mentor-Marcel R, Lamartiniere CA, Eltoum IE, Greenberg NM, Elgavish A. Genistein in the diet reduces the incidence of poorly differentiated prostatic adenocarcinoma in transgenic mice (TRAMP). Cancer Res. 2001; 61:6777-6782. [PubMed: 11559550]

188. Mentor-Marcel R, Lamartiniere CA, Eltoum IA, Greenberg NM, Elgavish A. Dietary genistein improves survival and reduces expression of osteopontin in the prostate of transgenic mice with prostatic adenocarcinoma (TRAMP). J Nutr. 2005; 135(5):989-995. [PubMed: 15867270]

189. McCormick DL, Johnson WD, Bosland MC, Lubet RA, Steele VE. Chemoprevention of rate prostate carcinogenesis by soy isoflavones and by Bowman-Birk inhibitor. Nutr Cancer. 2007; 57(2):184-193. [PubMed: 17571952]

190. Kumi-Diaka J, Merchant K, Haces A, Hormann V, Johnson M. Genistein-selenium combination induces growth arrest in prostate cancer cells. J Med Food. 2010; 13(4):842-850. [PubMed: 20553187]

191. Nakayama M, Gonzalgo ML, Yegnasubramanian S, Lin X, De Marzo AM, Nelson WG. GSTP1 $\mathrm{CpG}$ island hypermethylation as a molecular biomarker for prostate cancer. J Cell Biochem. 2004; 91:540-552. [PubMed: 14755684]

192. Yamasaki M, Mukai A, Ohba M, et al. Genistein induced apoptotic cell death in adult T-cell leukemia cells through estrogen receptors. Biosci Biotechnol Biochem. 2010; 74(10):2113-2115. [PubMed: 20944417]

193. Donzelli A, Braida D, Finardi A, Capurro V, Colleoni M, Sala M. Neuroprotective effects of genistein in mongolian gerbils: estrogen receptor- $\beta$ involvement. J Pharmacol Sci. 2010; 114(2): 158-167. [PubMed: 20962454]

194. Matsumura K, Tanaka T, Kawashima H, Nakatani T. Involvement of the estrogen receptor $\beta$ in genistein-induced expression of p21(waf1/cip1) in PC-3 prostate cancer cells. Anticancer Res. 2008; 28(2A):709-714. [PubMed: 18507011]

195. Iso T, Watanabe T, Iwamoto T, Shimamoto A, Furuichi Y. DNA damage cuased by bisphenol A and estradiol through estrogenic activity. Biol Pharm Bull. 2006; 29:206-210. [PubMed: 16462019]

196. Allen DL, Mitchner NA, Uveges TE, Nephew KP, Khan S, Ben-Jonathan N. Cell-specific induction of c-fos expression in the pituitary gland by estrogen. Endocrinology. 1997; 138(5): 2128-2135. [PubMed: 9112413]

197. Benker G, Jaspers C, Häusler G, Reinwein D. Control of prolactin secretion. Klin Wochenschr. 1990; 68(23):1157-1167. [PubMed: 2126309]

\section{Websites}

201. National Cancer Institute. Office of Budget and Finance. http://obf.cancer.gov

202. NIH. Estimates of Funding for Various Research, Condition and Disease Categories (RCDC). http://report.nih.gov/rcdc/categories 
Key issues

- Estrogens have been used to treat prostate cancer; however, these hormones and related compounds have also been identified as potential causative agents of prostate cancer.

- Evidence that supports estrogen as a prostate cancer-causing agent includes association of elevated levels of estrogen with prostate cancer, changes in estrogen receptor status in advanced prostate cancer, and rodent models and chimeric human tissue graft models showing induction of prostate cancer using estrogen plus testosterone.

- Early exposure to estrogens appears to predispose individuals to later development of prostate cancer.

- Potential mechanisms of estrogen-driven carcinogenesis include prostatic estrogen receptor-mediated events, epigenetic changes, genotoxicity, hyperprolactinemia and chronic inflammation.

- Future work on estrogen's role in the development and progression of prostate cancer is likely to include investigations of epigenetic changes, further elucidation of the role of individual estrogen receptor types using selective estrogen receptor modulators, and new models of developing human prostate tissue, including prostate stem/progenitor cells and xenografts. 


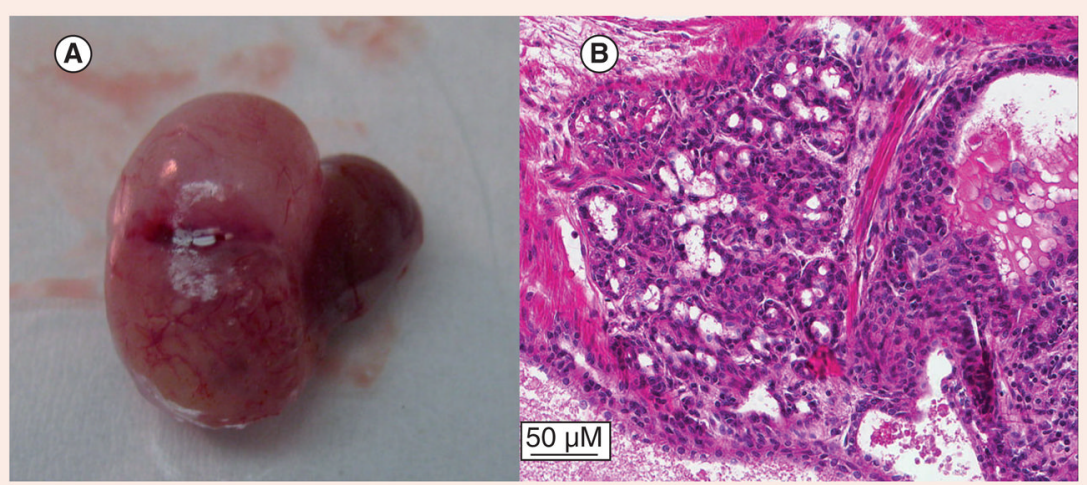

Figure 1. Renal graft of human prostate stem/progenitor cells recombined with rat urogenital mesenchyme following 3 months of elevated estradiol with testosterone support given to the host nude mouse

A locally invasive tumor can be seen in a prostate tissue xenograft after explantation (A). The tumor was induced using estrogen plus testosterone supplementation after implanting human epithelial progenitor cells and rat urogenital mesenchyme under the renal capsule of a nude mouse. Histopathology reveals that this tumor is prostatic adenocarcinoma (B). Images from [Prings GS et al., Unpublished Data]. 


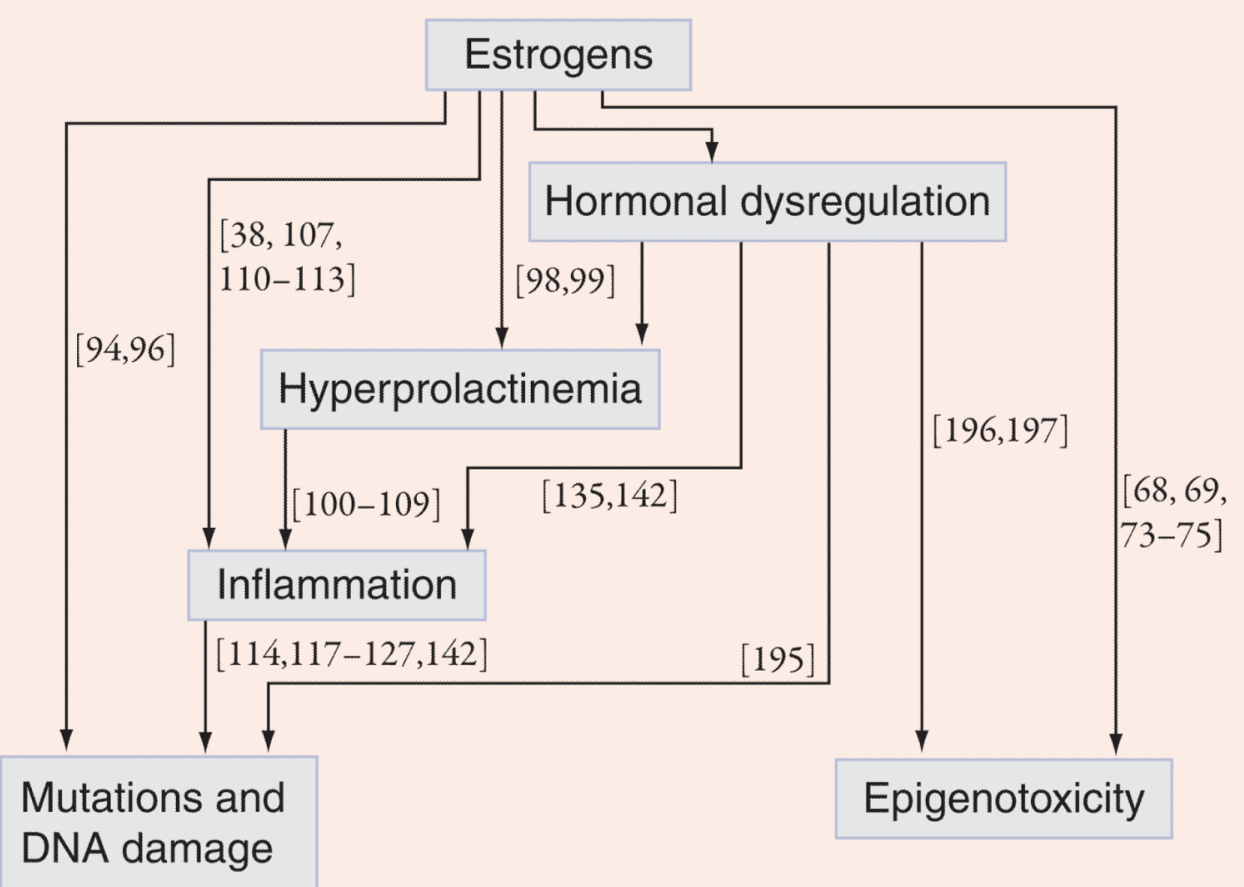

Figure 2. Diagram of proposed mechanisms of estrogenic carcinogenicity in the prostate Numbers refer to references supporting the corresponding pathway of estrogenic action. 
Table 1

Histopathologically identified locations of estrogen receptors, along with actions in prostate disease that have been identified.

\begin{tabular}{|lllll|}
\hline Receptor & Localization & Significant findings in prostate disease & Agonists & Antagonists \\
\hline ER $\alpha$ & Stroma and basal layer [126,130] & $\begin{array}{l}\text { Mediates inflammation [133,140] } \\
\text { Necessary for T + E model of rodent carcinogenesis [25] } \\
\text { Increased expression in high-grade disease [135] }\end{array}$ & $\begin{array}{l}\text { Estradiol } \\
\text { PPT }\end{array}$ & $\begin{array}{l}\text { ICI } \\
\text { Toremifene }\end{array}$ \\
& & $\begin{array}{l}\text { Blockade appears to reduce detection of CaP on subsequent } \\
\text { biopsy [143] }\end{array}$ & & \\
& & Predominant ER in developing human prostate [146] & Estradiol & ICI \\
ER $\beta$ & Stroma and basal layer [135] & $\begin{array}{l}\text { Increased affinity for phytoestrogens [144] } \\
\text { Reduced or absent in hormone-refractory disease [146] }\end{array}$ & DPN \\
& Epithelial [130,134] & Expression has inverse correlation with Gleason score [148,149] & & \\
& & Inhibits epithelial-mesenchymal transformation [150] & Estradiol & G-15 \\
& & Causes cell-cycle arrest in PC-3 cells [169] & ICI \\
GPR30 & Cytoplasmic membrane [138] & & G-1 \\
& & & & \\
\hline
\end{tabular}

CaP: Prostate cancer; DPN: Diarylpropionitrile; E: Estradiol 17ß; ER: Estrogen receptor; GPR: G-protein-coupled receptor; MPP: Methylpiperidino-pyrazole; PC: Prostate cancer; PPT: Propyl-pyrazole-triol; T: Testosterone; THC: Cis-tetrahydrochrysene. 